\title{
Antioxidant activities of chlorella extracts and physicochemical characteristics of spray-dried chlorella powders
}

\author{
Dae-Hoon Lee, Joo-Heon Hong* \\ Department of Food Science and Technology, Catholic University of Daegu, Gyeongsan 38430, Korea
}

클로렐라 추출물의 항산화 활성 및 분무건조 분말의 물리화학적 특성

\author{
이대훈·홍주헌* \\ 대구가톨릭대학교 식품공학전공
}

\begin{abstract}
In this study, extracts of chlorella using different extraction methods were compared for antioxidant activities and spray-dried chlorella powders were investigated for their physicochemical characteristics. The DPPH radical scavenging activity and superoxide radical scavenging activity of $50 \%$ ethanol extract were $29.19 \%$, and $48.91 \%$, respectively. The oxygen radical absorbance capacity (ORAC) of the $50 \%$ ethanol extract $(150.44 \mu \mathrm{M} / \mathrm{g}$ ) was higher than those of other extracts. The total chlorophyll content of the $50 \%$ ethanol extract $(542.89 \mathrm{mg} / 100 \mathrm{~g})$ was higher than those of other extracts. The microencapsulation of the $50 \%$ ethanol extract was manufactured by spray-drying with $10 \%$ maltodextrin (SD-C10), 20\% maltodextrin (SD-C20), and 30\% maltodextrin (SD-C30). The particle size of the freeze-dried powder $(454.47 \mu \mathrm{m})$ was higher than those of the spray-dried powders $(24.15 \sim 32.49 \mu \mathrm{m})$. Scanning electron microscope images showed that the spray-dried chlorella powders using SD-C10, SD-C20, and SD-C30 had an uniform particle distribution. The water absorption index and water solubility index (WSI) of powders were 0.31 0.45, and 96.96 $98.28 \%$, respectively. The spray-dried powders showed the stability in total chlorophyll content for 40 days storage. Based on these results, spray-dried chlorella powders could be used in various types of food processes.
\end{abstract}

Key words : chlorella, spray drying, microencapsulation, physicochemical characteristics, antioxidant activities

\section{서 론}

인체는 산화촉진물질(prooxidant)과 산화억제물질 (antioxidant)이 균형을 이루고 있으나 여러 가지 요인들에 의하여 산화촉진 쪽으로 기울게 되면, 산화적 스트레스 (oxidative stress)가 잠재적인 세포손상 및 병리적 질환을 일으키게 된다 $(1,2)$. 이러한 산화적 스트레스의 직접적인 원인이 되는 활성산소종(reactive oxygen species, ROS)은 불안정하고 반응성이 높아 여러 생체 물질과 쉽게 반응하

*Corresponding author. E-mail : jhhong@cu.ac.kr Phone : 82-53-850-3218, Fax: 82-53-850-3218

Received 15 July 2015; Revised 14 August 2015; Accepted 18 August 2015.

Copyright (c) The Korean Society of Food Preservation. All rights reserved.
고, 체내 고분자들을 공격하여 세포와 조직에 비가역적인 손상을 일으키거나 돌연변이, 세포독성 및 발암 등을 초래 하게 된다. 이런 관계로 활성산소를 소거하기 위한 항산화 성 물질을 식품이나 천연물에서 찾고자 하는 노력이 많이 시도되고 있다 $(3,4)$

최근 국내외적으로 미세조류에서 다양한 생리활성물질 이 발견되어, 이를 자원으로 이용하려는 연구가 활발히 진 행되면서 미세조류가 생산하는 고부가가치 생리활성물질 에 관심이 매우 증대되고 있다(5-7). 미세조류 중 클로렐라 (chlorella)는 담수에서 자라는 알칼리성 녹조류 중의 하나 이며, 인체에 필요한 영양소를 골고루 균형 있게 가지고 있으면서도 식이섬유소, 클로로필 및 카로티노이드 등의 생리활성물질을 많이 함유하고 있다 $(8,9)$. 현재 클로렐라는 식품의 1 차 및 2 차적 목적으로 사용되어 영양학적 우수성 이 확인되었으며 $(10,11)$, 항산화 활성이 우수한 기능성식품 
소재로 활용하기 위해서는 저렴한 비용으로 다량의 유용물 질을 생산할 수 있는 추출공정이 개발되어야 한다(12).

클로렐라에 함유되어 있는 지용성 색소인 엽록소 (chlorophyll)는 유용한 생리활성을 보유하고 있으나, 빛, 온도 및 금속이온 등에 의해 변색되기 쉽다(13). 특히 열에 의해서 페오피틴으로 분해가 되는데 이로 인하여 갈색의 탁하고 어두운 색으로 변화 되므로(14), 이를 해결하기 위한 연구가 선행되어야 한다. 분무건조 공정은 유용성분의 보 호를 목적으로 미세캡슐을 만드는 상업화된 방법 중 가장 보편화 된 것으로 그 생산량도 가장 많아 여러 분야에서 다양하게 이용되고 있다. 분무 건조된 입자는 피복물질 종류와 조성에 의해 그 특성이 결정된다고 보고되고 있으며 $(15,16)$, 피복물질은 주로 전분, 사이클로덱스트린, 말토덱 스트린, 셀룰로오스 및 다양한 다당류가 전통적으로 이용 되고 있다. 말토덱스트린은 D-glucose가 1차적으로 1-4 결 합으로 연결되어 있는 비영양원성 다당류로서 가격이 저렴 하여 분무건조시 피복물질로서 많이 이용되고 있으며, 산 소투과도를 감소시키는 특성이 있어 항산화제 없이도 안정 성이 우수하다(17).

따라서 본 연구에서는 클로렐라에 함유되어있는 유용물 질의 산업적 이용 증대의 일환으로 추출조건에 따른 클로렐 라 추출물의 항산화 활성 및 엽록소 함량을 분석하였으며, 클로렐라에 함유되어 있는 엽록소의 안정성 향상을 위해 피복물질을 이용하여 분무건조 분말을 제조한 다음 물리화 학적 특성을 조사하였다.

\section{재료 및 방법}

\section{실험재료}

본 실험에 사용된 재료는 수분 $7 \%$ 이하, 조단백질 $50 \%$ 및 엽록소 $2,000 \mathrm{mg} / 100 \mathrm{~g}$ 이상 함유된 클로렐라 원말을 (주)대상(Gunsan, Korea)으로부터 구입하여 사용하였으며, $-20^{\circ} \mathrm{C}$ 이하의 암소에 보관하면서 추출용 시료로 사용하였 다.

\section{추출물의 제조}

열수 및 $50 \%$ 에탄올 추출은 각각 시료 $10 \mathrm{~g}$ 에 $200 \mathrm{~mL}$ 의 증류수 및 $50 \%$ 에탄올을 첨가하고 $50^{\circ} \mathrm{C}$ 에서 4 시간 동안 환류 냉각추출기(CA-1112, Eyela Co., Tokyo, Japan)로 추출하였으 며, 가압추출은 autoclave(HB-506-4, Hanbaek Sci Co., Bucheon, Korea)를 이용하여 $121^{\circ} \mathrm{C}$ 에서 15 분간 추출하였다. 효소처리 추출은 시료 $10 \mathrm{~g}$ 에 $200 \mathrm{~mL}$ 의 증류수를 가한 다음 shaking incubator(BS-31, Jeio Tech, Daejeon, Korea)를 이용하 여 $160 \mathrm{rpm}$ 에서 $\mathrm{pH}$ 를 4.8로 조정한 다음 세포벽 분해효소 (Celluclast 1.5L, Novozyme Co., Bagsvaerd, Denmark)를 시료 중량 대비 $2 \%$ 의 농도로 첨가하여 $50^{\circ} \mathrm{C}$ 에서 1 시간 동안 1 차
가수분해 하였다. 1 차 가수분해 후 $\mathrm{pH}$ 를 8.0 으로 재조정 한 다음 단백질분해효소(Alcalase, Novozyme Co., Bagsvaerd, Denmark)를 시료 중량 대비 $2 \%$ 의 농도로 첨가하여 $50^{\circ} \mathrm{C}$ 에서 1 시간 동안 2 차 효소분해 하였다. 추출물은 감압농축기 $(\mathrm{N}-1 \mathrm{~N}$, Eyela Co., Tokyo, Japan)로 농축하였으며, 동결건조(FreeZone 2.5, Labconco Co., St. Louis, MO, USA)하여 $-70^{\circ} \mathrm{C}$ 이하의 암소에 보관하면서 분석용 시료로 사용하였다.

\section{$\mathrm{DPPH}$ radical 소거 활성 측정}

DPPH radical 소거활성은 1,1-diphenyl-2-picrylhydrazyl (DPPH, Sigma-Aldrich Co., St. Louis, MO, USA)의 환원력 을 이용하여 측정하였다(18). 즉, 시료 $0.5 \mathrm{~mL}$ 에 $4 \times 10^{-4} \mathrm{M}$ $\mathrm{DPPH}$ 용액(99.9\% ethyl alcohol에 용해) $5 \mathrm{~mL}$ 를 혼합하여 실온에서 15 분간 반응 시킨 다음 분광광도계(Ultraspec 2100pro, Biochrom Ltd., Cambridge, UK)를 이용하여 517 $\mathrm{nm}$ 에서 흡광도를 측정하였다. DPPH radical 소거 활성은 추출물의 첨가 전과 후의 차이를 아래와 같이 백분율로 나타내었다.

DPPH radical scavenging activity $(\%)=$

$$
\left(1-\frac{\text { sample absorbance }}{\text { control absorbance }}\right) \times 100
$$

\section{Superoxide radical 소거 활성 측정}

Superoxide radical 소거 활성은 Nishikimi(19)의 방법에 따라 다음과 같이 측정하였다. 시료 $500 \mu \mathrm{L}$ 에 $0.1 \mathrm{M}$ Tris- $\mathrm{HCl}$ 완충용액( $\mathrm{pH}$ 8.5) $100 \mu \mathrm{L}, 100 \mu \mathrm{M}$ phenazine methosulfate(PMS, Sigma-Aldrich Co.) $200 \mu \mathrm{L}$ 를 혼합하여 반응 시킨 후 $500 \mu \mathrm{M}$ nitro blue tetrazolium(NBT, Sigma-Aldrich Co.) $200 \mu \mathrm{L}$ 및 $500 \mu \mathrm{M} \beta$-nicotinamise adenine dinucleotide(NADH, Sigma-Aldrich Co.) $400 \mu \mathrm{L}$ 를 첨가하여 실온에서 10 분간 반응시킨 다음 분광광도계 (Ultraspec 2100pro, Biochrom Ltd.)를 이용하여 $560 \mathrm{~nm}$ 에서 흡광도를 측정하였다. Superoxide radical 소거활성은 추출 물의 첨가 전과 후의 차이를 아래와 같이 백분율로 나타내 었다.

Superoxide radical scavenging activity $(\%)=$

$$
\left(1-\frac{\text { sample absorbance }}{\text { control absorbance }}\right) \times 100
$$

ORAC (oxygen radical absorbance capacity) 측정

ORAC 측정은 Talcott와 Lee(20)가 항산화 활성 측정에 사용한 분석법을 이용하였다. 클로렐라 추출물 동결건조 분말 및 Trolox를 농도별로 희석하였으며, 실험용 시료의 제조에는 중성 phosphate buffer(61.6:38.9, v/v, $0.75 \mathrm{M}$ $\mathrm{K}_{2} \mathrm{HPO}_{4}$ 와 $0.75 \mathrm{M} \mathrm{NaH}_{2} \mathrm{PO}_{4}$ )를 사용하였다. 검량 곡선을 작성하기 위하여 항산화 활성 비교 표준액으로 water 
soluble analogue of vitamin E, 6-hydroxy-2,5,7,8-tetramethylchroman-2-carboxylic acid(Trolox, Sigma-Aldrich Co.) 10 $\mu \mathrm{L}$ 를 phosphate buffer $50 \mathrm{~mL}$ 에 용해하여 제조하였고, 측정 기기는 fluorescent micro plate reader(Infinite M200 PRO, Tecan Co., Salzburg, Austria)를 사용하여 $485 \mathrm{~nm}$ 에서 전자 가 여기(excitation)되고 $538 \mathrm{~nm}$ 에서 방출(emission)되게 조 절하여 본 실험에 적용되었다.

\section{총 엽록소함량 측정}

총 엽록소함량 측정은 $\mathrm{Kim}$ 등(21)의 방법에 의해 다음과 같이 측정하였다. 시료 $0.05 \mathrm{~g}$ 과 증류수 $10 \mathrm{~mL}$ 를 30 분간 초음파 처리(VCX 400, Sonic \& Materials Inc., Newtown, $\mathrm{CT}, \mathrm{USA}$ )를 한 다음 현탁액 $2 \mathrm{~mL}$ 를 취하여 차광한 원심분 리관에 넣고 알카리성 pyridine(Duksan Pure Chemicals, Seoul, Korea) 용액 $5 \mathrm{~mL}$ 를 가한 후 $60^{\circ} \mathrm{C}$ 수욕 상에서 15 분간 초음파 처리를 하였다. 3 분간 $4{ }^{\circ} \mathrm{C}$ 에서 $3,000 \mathrm{rpm}$ 으로 원심 분리(VS-6000CFN, Vision Scientific Co., Ltd., Bucheon, Korea)를 한 다음 상층액을 $10 \mathrm{~mL}$ 갈색 mess-flask에 옮긴 후 남아 있는 잔사는 반복 처리하여 최종 $10 \mathrm{~mL}$ 가 되도록 하였다. 알카리성 pyridine(Duksan Pure Chemicals.)용액을 대조군으로 하여 액층 $1 \mathrm{~cm}$, 파장 $419 \mathrm{~nm}$ 와 $454 \mathrm{~nm}$ 에서 흡광도(Ultraspec 2100pro, Biochrom Ltd.)를 측정하였다.

Total chlorophyll $(\mathrm{mg} / 100 \mathrm{~g})=\mathrm{C} / \mathrm{S} \times 100$

C : Chlorophyll $(\mathrm{mg} / \mathrm{L})=8.970 \times(7.19 \mathrm{E} 419 \mathrm{~nm}+3.33 \mathrm{E} 454 \mathrm{~nm})$

$\mathrm{S}$ : Sample weight $(\mathrm{mg}) / 5$

E419 nm : OD $419 \mathrm{~nm}$

$\mathrm{E} 454 \mathrm{~nm}$ : OD $454 \mathrm{~nm}$

\section{분무건조 분말 제조}

분무건조 공정을 이용한 분말 제조는 $3.5^{\circ} \mathrm{Brix}$ 의 $50 \%$ 에탄올 추출물 $500 \mathrm{~mL}$ 에 말토덱스트린을 각각 $10 \%$ (SD-C10), $20 \%(\mathrm{SD}-\mathrm{C} 20)$ 및 $30 \%(\mathrm{SD}-\mathrm{C} 30)$ 를 첨가한 다음 homogenizer(HG-15D, Daihan scientific Co., Wonju, Korea) 를 이용하여 $4,000 \mathrm{rpm}$ 에서 15 분간 균질화하였다. 제조된
균질액은 주입 온도 $170^{\circ} \mathrm{C}$, 방출 온도 $110^{\circ} \mathrm{C}$ 로 설정하였고, 분무속도는 $17,000 \mathrm{rpm}$ 에서 시료공급속도는 $12 \mathrm{~mL} / \mathrm{min}$ 의 조건으로 아토마이저(atomizer)가 장착된 분무건조기 (KL-8, Seogang Engineering Co., Ltd., Cheonan, Korea)를 이용하여 분무건조 분말을 제조한 다음, $-70^{\circ} \mathrm{C}$ 이하의 암 소에 보관하면서 분석용 시료로 사용하였다.

\section{입자크기 및 입자모양 측정}

입자크기는 레이저입도분석기(LS-13-320, Beckman coulter, Fullerton, CA, USA)를 이용하여 isopropyl alcohol에 분산시켜 측정하였다. 입자표면구조는 각 시료에 gold ion coating한 후 주사형 전자현미경(S-4800, Hitachi highTechnologies Co., Tokyo, Japan)을 이용하여 $3.0 \mathrm{kV}$ 에서 500 배 비율로 관찰하였다.

\section{수분흡수지수 및 수분용해지수 측정}

수분흡수지수(water absorption index, WAI) 및 수분용해 지수(water solubility index, WSI) 측정은 phillips의 방법(22) 을 변형하여 측정하였다. 동결건조 및 분무건조 분말 0.5 $\mathrm{g}$ 에 $20 \mathrm{~mL}$ 증류수를 첨가하여 $3,000 \mathrm{rpm}$ 에서 20 분간 원심 분리(VS-6000CFN, Vision scientific Co.) 한 후 침전물은 수분흡수지수로 사용하였으며, 상등액은 미리 무게를 구한 수기에 분리하여 $105^{\circ} \mathrm{C}$ 에서 4 시간 동안 건조시킨 고형분을 수분용해지수로 사용하여 아래와 같이 계산하였다.

$$
\text { WAI }=\frac{\text { Hydrated sample weight }- \text { Dry sample weight }}{\text { Dry sample weight }}
$$

WSI $(\%)=\frac{\text { Dry solid weight recovered by evaporating the supernatant }}{\text { Dry sample weight }} \times 100$

\section{분무건조 분말의 저장 안정성 분석}

클로렐라 분무건조 분말의 저장기간에 따른 안정성은 분무건조 분말을 실온의 데시케이터(desiccator, ø240, $1 \mathrm{klab}$ Co., Namyangju, Korea)에 40일간 저장하면서 총 엽록소

Table 1. DPPH radical scavenging activity, superoxide radical scavenging activity, ORAC (oxygen radical absorbance capacity) of extracts from chlorella

\begin{tabular}{|c|c|c|c|}
\hline Extraction conditions & $\begin{array}{l}\text { DPPH radical scavenging activity } \\
\qquad(5 \mathrm{mg} / \mathrm{mL}, \%)\end{array}$ & $\begin{array}{l}\text { Superoxide radical scavenging activity } \\
\qquad(5 \mathrm{mg} / \mathrm{mL}, \%)\end{array}$ & $\begin{array}{c}\text { ORAC } \\
\text { (Trolox } \mu \mathrm{M} / \mathrm{g} \mathrm{FW} \text { ) }\end{array}$ \\
\hline Hot water extraction & $11.47 \pm 0.64^{1) e 2)}$ & $28.46 \pm 3.37^{\mathrm{d}}$ & $62.39 \pm 7.15^{\mathrm{c}}$ \\
\hline $50 \%$ ethanol extraction & $29.19 \pm 0.37^{b}$ & $48.91 \pm 0.84^{b}$ & $150.44 \pm 4.45^{\mathrm{a}}$ \\
\hline Pressurized extraction & $14.58 \pm 0.95^{\mathrm{d}}$ & $32.96 \pm 4.84^{\mathrm{c}}$ & $120.43 \pm 11.64^{b}$ \\
\hline Enzyme extraction & $17.39 \pm 0.30^{c}$ & $35.86 \pm 4.14^{\mathrm{c}}$ & $134.04 \pm 11.57^{b}$ \\
\hline Positive control ${ }^{3)}$ & $95.75 \pm 0.51^{\mathrm{a}}$ & $94.58 \pm 2.56^{\mathrm{a}}$ & - \\
\hline
\end{tabular}

${ }^{1)}$ The values are mean $\pm \mathrm{SD}$ of three experimental data.

${ }^{2)}$ Mean \pm SD ( $n=3$ ) within each column (a-e) followed by the same letter are not significantly different $(\mathrm{p}<0.05)$.

${ }^{3)}$ Positive control : ascorbic acid (DPPH radical scavenging activity) and catechin (superoxide radical scavenging activity) solution were measured at $1 \mathrm{mg} / \mathrm{mL}$, respectively. 
함량을 측정하였다. 저장안정성 평가를 위한 대조구로는 클로렐라 $50 \%$ 에탄올 추출물 동결건조 분말을 사용하여 비교 하였다.

\section{통계 처리}

실험결과는 3회 반복으로 행하여 평균 \pm 표준편차로 나타 내었으며 SPSS(19.0, SPSS Inc., Chicago, IL, USA)를 이용 하여 분산분석(ANOVA)을 실시하였으며, 각 측정 평균값 의 유의성 $(\mathrm{p}<0.05)$ 은 Duncan's multiple range test로 검정하 였다.

\section{결과 및 고찰}

\section{항산화활성}

추출조건에 따른 클로렐라 추출물의 항산화 활성은 $\mathrm{DPPH}$, superoxide radical 소거 활성 및 ORAC 방법으로 분석하여 Table 1에 나타내었다. DPPH radical 소거 활성은 $50 \%$ 에탄올 추출물에서 $29.19 \%$ 로 가장 높은 활성을 나타 내었으며, 가압 $14.58 \%$, 효소처리 $17.39 \%$ 및 열수 추출 $11.47 \%$ 순이었다. Son 등(23)은 스피루리나 효소 가수분해 물의 생리활성 연구에서 $5 \mathrm{mg} / \mathrm{mL}$ 농도로 DPPH radical 소거 활성을 측정한 결과 약 $10 \%$ 미만의 낮은 소거 활성을 나타내었다고 보고하였으며, Kim 등(24)은 해양 미세조류 의 항산화성 연구에서 지용성 용매 및 수용성 용매로 추출 하여 항산화 활성을 측정한 결과 지용성 용매 추출물에서 항산화 활성이 우수하여 본 연구결과와 유사한 경향을 나타 내었다.

Superoxide radical 소거 활성을 조사한 결과 $50 \%$ 에탄올 추출물은 $48.91 \%$, 열수추출물에서 $28.46 \%$ 로 측정되어 $50 \%$ 에탄올 추출물에서 radical 소거 활성이 우수하였으며, 가압 및 효소처리 추출은 각각 $32.96 \%$ 및 $35.86 \%$ 로 유의적 인 차이를 나타내지 않았다. Woo 등(25)은 가압 열처리가 톱풀과 울릉미역취 어린잎의 항산화 활성에 미치는 영향 연구에서 $121^{\circ} \mathrm{C}$ 열처리에 의하여 radical 소거능이 현저히 저하되었는데, 이는 생리활성물질의 종류와 결합 정도에 따른 차이라고 보고하였다. ORAC(oxygen radical absorbance capacity)분석은 $\mathrm{AAPH}$ 로부터 유도된 peroxyl radical에 대 한 소거활성을 형광도로 측정하며, peroxyl radical 손상에 대한 억제 시간과 억제율을 모두 반영하는 측정 방법이다 (26). ORAC 측정결과 50\% 에탄올 추출에서 $\mathrm{g}$ 당 150.44 $\mu \mathrm{M}$ 로 가장 우수한 값을 나타내었으며, 효소처리 134.04 $\mu \mathrm{M}$, 가압 120.43 및 열수추출 $62.39 \mu \mathrm{M}$ 순으로 분석되었다. Guzman 등(27)은 클로렐라가 활성산소 등 자유 유리기 생 성을 저해시키는 항산화 활성을 가지고 있음을 확인하였으 며, Kumar 등(28)과 Kamat 등(29)은 엽록소의 수용성 성분 인 클로로필린(chlorophyllin)은 활성 산소종을 제거하는 능
력이 있다고 보고하였다.

\section{총 엽록소함량}

추출조건에 따른 클로렐라 추출물의 총 엽록소 함량은 Fig. 1과 같다. 총 엽록소 함량은 $50 \%$ 에탄올 추출물이 100 $\mathrm{g}$ 당 $542.89 \mathrm{mg}$ 로 가장 많이 함유하고 있었으며, 효소처리 $150.58 \mathrm{mg}$, 가압 $110.61 \mathrm{mg}$ 및 열수 $93.88 \mathrm{mg}$ 순으로 총 엽록소 함량을 나타내었다. Kim 등(21)은 신 제형 클로렐라 제품의 총 엽록소 시험법 개선 연구에서 시중에 판매되고 있는 클로렐라 제품의 총 엽록소 함량은 시럽제품에서 100 $\mathrm{g}$ 당 $30.8 \mathrm{mg}$, 타블렛 제품은 $123.7 \mathrm{mg}$ 함유하고 있다고 보고하였다. 이는 본 연구에서 수행된 $50 \%$ 에탄올 및 효소 처리 추출의 경우 시중 제품에 비해 총 엽록소 함량이 우수 하였으며, $50 \%$ 에탄올 추출 조건은 클로렐라의 유용물질인 총 엽록소를 가장 높게 함유하고 있었다. 클로렐라는 건강 기능식품공전에 피부건강 및 항산화작용 기능성에 대해 등재되어 있으며, 산업적 이용 증대를 위해 산, 알칼리, 염 류, 금속이온, 빛 및 가열 등에 의해 영향을 받는 엽록소의 파괴를 최소한으로 감소시킬 수 있는 공정이 필요할 것으로 사료된다(30).

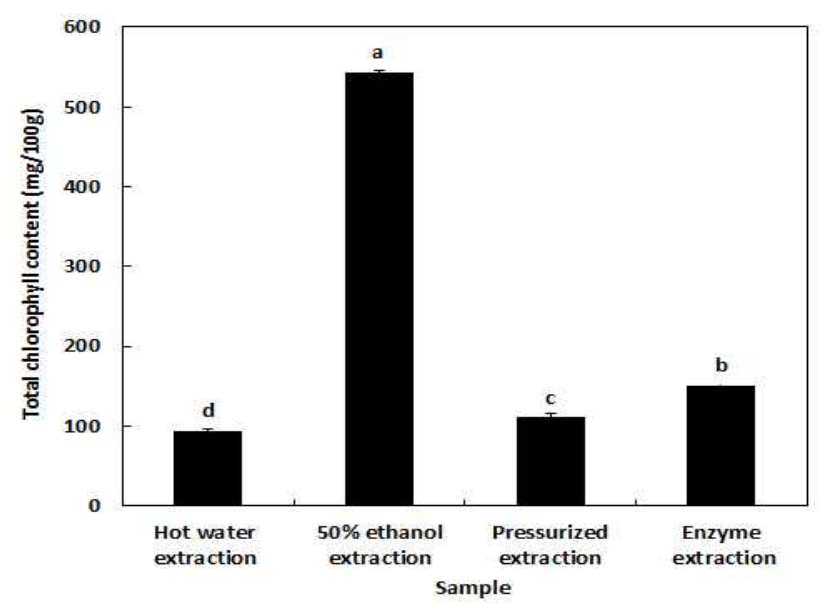

Fig. 1. Total chlorophyll content of extracts from chlorella. Means with different superscripts are significantly different at $p<0.05$.

\section{분무건조 분말의 입자크기 및 입자표면구조}

클로렐라 분무건조 분말의 입자크기 및 입자표면구조는 Table 2와 Fig. 2에 나타내었다. 입자크기의 경우 동결건조 분말의 $454.47 \mu \mathrm{m}$ 에 비하여 분무건조 분말이 $24.15 ~ 32.49$ $\mu \mathrm{m}$ 로 유의적으로 낮은 크기를 나타내었다. 말토덱스트린 첨가량이 높아질수록 분무건조 분말의 입자크기가 커지는 경향이었으나, 통계적으로 유의적인 차이는 나타나지 않았 다. Park 등(31)은 $\beta$-carotene을 말토덱스트린을 첨가하여 분무건조된 분말의 입자크기를 측정한 결과 평균적으로 30 40 $\mu \mathrm{m}$ 범위의 분말이 분포한다고 보고하였다. 또한 Rosenberg 등(32)은 입자크기가 작을수록 내부 물질을 포접 
하는데 유리하다는 연구결과에 따라 분무건조 분말에서 클로렐라 엽록소의 저장 안정성이 우수할 것으로 기대된 다. 클로렐라 동결건조 분말의 표면구조는 조직이 빙결정 형성 후 승화로 인해 건조되어 표면 구조가 매우 거친 모양 을 나타내었으나, 분무건조 분말의 경우 전반적으로 구형 의 모양을 보여주어 분말 흐름성이 양호할 것으로 사료된 다. Lee(33)는 젖산균의 미세캡슐화와 생존에 관한 연구에 서 분말의 형태는 온도에 큰 영향을 받는데, 온도가 높으면 분무 효율이 높아 구형이 형성 된다고 하였으며, 말토덱스 트린 첨가량이 높아질수록 움푹 들어간 자국들의 증가는, $\operatorname{Kim}$ 등(34)의 부형제 종류에 따른 곰취 착즙액 분무건조 분말 연구에서 건조 과정 중 입자들이 수축함에 따른 현상 이라 보고 하였다.

\section{수분흡수지수 및 수분용해지수}

클로렐라 추출물 분무건조 분말의 수분흡수지수(WAI) 및 수분용해지수(WSI)는 Table 2와 같다. 분말의 수분흡수 지수 및 수분용해지수는 식품산업 활용 측면에서 중요한 가공적성 요인으로 알려져 있다(35). 수분흡수지수는 말토 덱스트린 첨가 분무건조 분말에서 $0.31 ~ 0.45$ 로 동결건조 분말 0.85 보다 낮은 흡수 지수를 나타내었다. Beom 등(36) 은 열풍건조와 동결건조에 따른 수창포 분말의 수분흡수지

Table 2. Particle size, water absorption index (WAI) and water solubility index (WSI) and of microencapsulated from chlorella extract

\begin{tabular}{cccc}
\hline Powder Sample $^{\mathrm{l})}$ & Particle size $(\mu \mathrm{m})$ & WAI & WSI $(\%)$ \\
\hline FD & $\left.454.47 \pm 11.96^{2 \mathrm{a} 3}\right)$ & $0.85 \pm 0.01^{\mathrm{a}}$ & $80.03 \pm 0.13^{\mathrm{d}}$ \\
SD-C10 & $24.15 \pm 0.50^{\mathrm{b}}$ & $0.45 \pm 0.03^{\mathrm{b}}$ & $96.96 \pm 0.17^{\mathrm{c}}$ \\
SD-C20 & $28.10 \pm 1.30^{\mathrm{b}}$ & $0.35 \pm 0.01^{\mathrm{c}}$ & $97.65 \pm 0.17^{\mathrm{b}}$ \\
SD-C30 & $32.49 \pm 0.03^{\mathrm{b}}$ & $0.31 \pm 0.02^{\mathrm{d}}$ & $98.28 \pm 0.43^{\mathrm{a}}$ \\
\hline
\end{tabular}

${ }^{1)} \mathrm{FD}$, freeze-dried powder; SD-C10, spray-dried powder added 10\% maltodextrin; SD-C20, spray-dried powder added $20 \%$ maltodextrin; SD-C30, spray-dried powder added $30 \%$ maltodextrin.

${ }^{2}$ The values are mean $\pm \mathrm{SD}$ of three experimental data.

${ }^{3)}$ Mean $\pm \mathrm{SD}(\mathrm{n}=3$ ) within each column (a-d) followed by the same letter are not significantly different $(\mathrm{p}<0.05)$.
수에서 동결건조가 열풍건조에 비하여 높았다고 보고하여 본 연구결과와 유사하였다. 흡습특성의 경우 조직구조와 밀접한 관계가 있는 점을 고려해 볼 때 낮은 수분흡수지수 를 나타내는 것은 분무효율의 증가 및 균일한 입자분포를 나타낼 것으로 사료된다.

수분용해지수는 분무건조 분말에서 96.96 98.28\%로 동 결건조 분말 $80.03 \%$ 에 비해 높은 용해지수를 나타내었다. Park 등(37)은 분무건조공정을 이용한 파인애플 착즙액 분 무건조 분말의 수분용해지수를 측정한 결과 말토덱스트린 첨가 분무건조 분말에서 동결건조에 비해 용해지수가 높아 진다고 보고하여 본 연구결과와 유사하였다. 이는 분무건 조 분말에 사용된 말토덱스트린의 당에 의해 수산기와 이중 층 표면에 있는 인산염기 간 상호작용이 일어남에 따라 용해성은 증가한 것으로 사료된다.

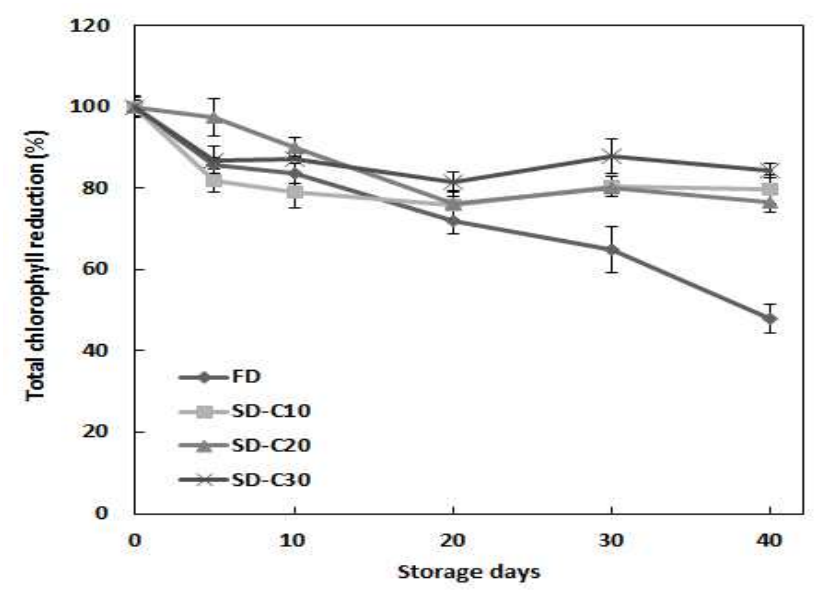

Fig. 3. Changes in total chlorophyll content of microencapsulated from chlorella extract during storage (40 days) at room temper ature.

FD, freeze dried powder; SD-C10, spray-dried powder added 10\% maltodextrin; SD-C20, spray-dried powder added 20\% maltodextrin; SD-C30, spray-dried powder added 30\% maltodextrin.

\section{분무건조 분말의 총 엽록소 안정성}

클로렐라 분무건조 분말의 저장기간에 따른 총 엽록소 함량의 감소율을 Fig. 2에 나타내었다. 저장 중 분무건조

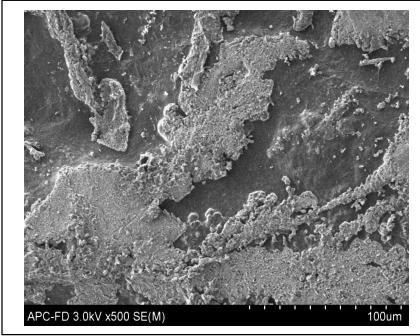

(A) FD

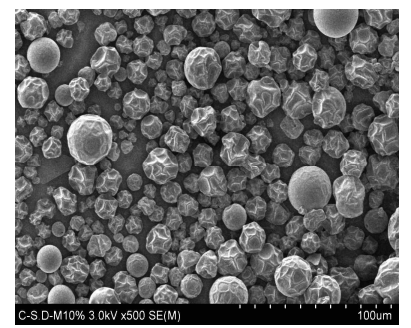

(B) $\mathrm{SD}-\mathrm{C} 10$

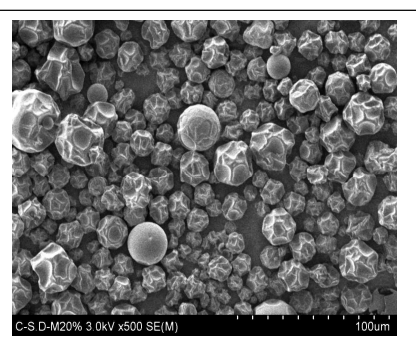

(C) SD-C20

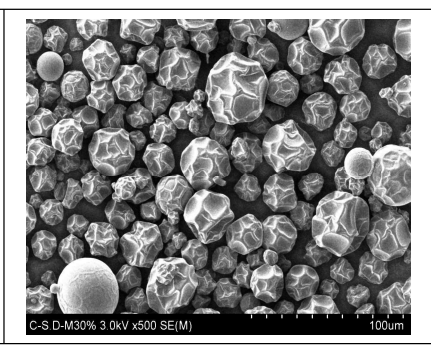

(D) SD-C30

Fig. 2. Scanning electron microscope (magnification $\times 500$ ) of microencapsulated from chlor ella extract.

FD, freeze-dried powder; SD-C10, spray-dried powder added 10\% maltodextrin; SD-C20, spray-dried powder added 20\% maltodextrin; SD-C30, spray-dried powder added 30\% maltodextrin. 
분말의 초기 총 엽록소 함량은 $100 \mathrm{~g}$ 당 $48.87 \sim 107.26 \mathrm{mg}$ 으 로 말토덱스트린 첨가량이 높아질수록 총 엽록소 함량은 낮게 나타났으며, 동결건조 분말에서 $542.89 \mathrm{mg}$ 으로 총 엽록소를 가장 많이 함유하고 있었다. 저장 40 일 이 후 분무 건조 분말은 $100 \mathrm{~g}$ 당 $41.21 ~ 85.48 \mathrm{mg}$ 의 총 엽록소 함량을 유지하여 15.67 20.31\% 감소하였고 말토덱스트린 첨가에 의해 저장 안정성이 우수하게 나타났다. 동결건조 분말에 서는 저장 40 일 이 후 $259.87 \mathrm{mg}$ 의 총 엽록소 함량을 유지하 여 $52.13 \%$ 감소율을 나타내어 저장 안정성이 낮아짐을 알 수 있었다. Bae와 Kim (38)의 분무건조를 통한 아보카도 오일의 클로로필 저장 안정성 연구에서 캡슐화된 시료는 대조군 보다 안정하다고 보고하여 본 연구결과와 유사한 경향을 나타내었다. 이는 말토덱스트린은 산소가 투과하기 어려운 매트릭스를 생성하기 때문에 저장기간을 향상시켜 주는 결과를 나타낸 것으로 사료된다(39). 따라서, 본 연구 에서 클로렐라에 말토덱스트린을 첨가하여 분무건조 분말 제조를 통해 엽록소의 안정성 향상을 통한 산업적 이용가능 성이 기대된다.

\section{요 약}

본 연구에서는 다양한 생리활성을 가지고 있는 클로렐라 의 기능성식품소재로의 산업적 이용 증대를 위해 추출조건 에 따른 항산화 활성 및 총 엽록소 함량을 조사하였고 엽록 소의 안정성 향상을 위해 분무건조 분말을 제조하여 물리화 학적 특성을 확인하였다. 추출조건에 따른 $\mathrm{DPPH}$ 및 superoxide radicle 소거활성은 $50 \%$ 에탄올 추출물에서 각 각 $29.19 \%$ 및 $48.91 \%$ 로 가장 높은 활성을 나타내었으며, ORAC은 $50 \%$ 에탄올 추출물에서 $\mathrm{g}$ 당 $150.44 \mu \mathrm{M}$ 로 가장 높은 값을 나타내었다. 총 엽록소 함량은 $50 \%$ 에탄올 추출 물에서 $100 \mathrm{~g}$ 당 $542.89 \mathrm{mg}$ 으로 가장 높은 함량을 나타내었 다. 입자크기는 분무건조 분말에서 24.15 32.49 $\mu \mathrm{m}$ 로 동결 건조 분말의 $454.47 \mu \mathrm{m}$ 보다 작았으며, 표면구조는 전반적 으로 구형을 나타내었으나, 말토덱스트린이 첨가량이 증가 함에 따라 표면 굴곡이 증가함을 확인하였다. 수분흡수지 수는 분무건조 분말에서 $0.31 \sim 0.45$ 로 동결건조 분말 0.85 에 비해 낮은 흡수지수를 나타내었으며, 수분용해지수는 분무 건조 분말에서 96.96 98.28\%로 동결건조 분말의 $80.03 \%$ 보다 높게 나타났다. 분무건조 분말의 저장 안정성은 총 엽록소 함량의 감소율로 확인하였는데, $15.67 ~ 20.31 \%$ 감소 하여 동결건조 분말보다 우수하였다. 따라서 클로렐라 추 출물 제조에 $50 \%$ 에탄올을 용매로 사용하였을 때, 항산화 활성 및 엽록소 함량이 우수하였으며 클로렐라 추출물에 말토덱스트린을 첨가한 분무건조 분말에서 엽록소의 안정 성이 증가하였다. 특히 총 엽록소 함량 및 가공비용 등을 고려하였을 때 말토덱스트린 $10 \%$ 첨가량이 산업적으로 적용가능하다 판단된다.

\section{감사의 글}

본 논문은 2014년도 대구가톨릭대학교 교내연구비 지원 에 의한 것으로 감사드립니다.

\section{References}

1. Koh YJ, Cha DS, Choi HD, Park YK, Choi IW (2008) Hot water extraction optimization of Dandelion leaves to increase antioxidant activity. Korean J Food Sci Technol, 40, 283-289

2. Halliwell B, Aruoma OJ (1991) DNA damage by oxygen-derived species. FEBS Lett, 281, 9-19

3. Jennings PE, Barnett AH (1988) New approaches to the pathogenesis and treatment of diabetic microangiopathy. Diabetic Med, 5, 111-117

4. Fridovich I (1989) Superoxide dismutase an adaption to paramagnetic gas. J Biol Chem, 264, 7761-7762

5. Kang MS, Sim SJ, Chae HJ (2004) Chlorella as a functional biomaterial. Korean J Biotechanol Bioeng, 15, 113-118

6. Miguel O (2003) Commercial development of microalgal biotechnology : from the test tube to the marcketplace. Biomol Eng, 20, 459-466

7. Bajguz A (2000) Effect of brassinosteroids on nucleic acids and protein content in cultured cells of Chlorella vulgaris. Plant Physiol Biochem, 38, 209-215

8. Borowitzka MA (1986) Micro-algae as sources of fine chemicals. Microbiol Sci, 3, 372-375

9. Kay PA (1991) Microalgae as food and supplement. Crit Rev Food Sci Nutr, 30, 555-573

10. Kim SS, Park MK, Oh NS, Kim DC, Han MS, In MJ (2003) Studies on quality characteristics and shelf-life of chlorella soybean. J Korean Soc Agric Chem Biotechnol, 46, 12-15

11. Park MK, Lee JM, Park CH, In MJ (2002) Quality characteristics of sulgidduk containing Chlorella powder. J Korean Soc Food Sci Nutr, 31, 225-229

12. Shin SL, Lee CH (2011) Antioxidant activities of ostrich fern by different extraction methods and solvents. J Life Sci $21,56-61$

13. Lee IS, Lee HY, Kim HL, Ko KH, Chang HC, Kim IC (2008) Effect of metal ions on stabilization of Codium fragile's pigments. Korean J Food Preserv, 3, 352-360

14. Bae EK, Kim GH (2008) Encapsulation of avocado oil using spray drying. Korean J Food Sci Technol, 40, 303-310

15. Hogan SA, McNamee BF, O'Riordan ED, O'Sullivan 
M (2001) Emulsification and microencapsulation properties of sodium caseinate/carbohydrate blends. Int Dairy J, 11, 137-144

16. Boatright WL, Hettiarachchy NS (1995) Spray-drided soy protein isolate solubility, gelling characteristics and extractable protein as affected by antioxidants. J Food Sci, 60, 806-809

17. Dzondo-Gadet A, Nzikou JM, Etoumongo A, Linder A, Desobry S (2005) Encapsulation and storage of safou pulp oil in 6DE maltodextrins. Process Biochem, 40, 265-271

18. Son JY, Kim TO (2011) Antioxidative and physiological activities of traditional Korean teas. Korean J Food Cookery Sci, 27, 567-575

19. Nishikimi M, Rao NA, Yagi K (1972) The occurrence of superoxide anion in the reaction of reduced phenazine methosulfate and molecular oxygen. Biochem Biophys Res Commun, 46, 849-854

20. Talcott ST, Lee JH (2002) Ellagic acid and flavonoid antioxidant content of mascadine wine and juice. J Agri Food Chem, 50, 3186-3192

21. Kim YK, Lee ES, Han JG, No GM, Lim DG, Jung JY, Park YS (2011) Improvement of total chrolophill analytical methods for the chlorella products with extended products types. J Fd Hyg safety, 26, 70-75

22. Phillips RD, Chinnan MS, Granch AI, Miller J, Mcwatters $\mathrm{KH}$ (1998) Effects of pre-treatment on functional and nutritional properties of cowpea meal. J Food Sci, 53, 805-809

23. Son MH, Park KH, Choi AR, Yoo GJ, In MJ, Kim DH, Chae HJ (2009) Investigation of biological activities of enzymatic hydrolysate of spirulina. J Korean Soc Food Sci Nutr, 38, 136-141

24. Kim SK, Baek HC, Byun HG, Kang OJ, Kim JB (2001) Biochemical composition and antioxidative activity of marine microalgae. J Korean Fish Soc, 34, 260-267

25. Woo JH, Shin SL, Jeong HS, Lee CH (2010) Influence of applied pressure and heat treatment on antioxidant activities of young leaves from Achillea alpina and Solidago virgaurea subsp. gigantea. Korean J Plant Res, 23, 123-130

26. Alarcon E, Campos AM, Edwards AM, Lissi E, Lopez-Alarcon C (2008) Antioxidant capacity of herbal infusions and tea extracts : a comparison of ORACfluorescein and ORAC-pyrogallol red methodologies. Food Chem, 107, 1114-1119

27. Guzman S, Gato A, Calleja JM (2001) Antiinflammatory, analgesic and free radical scavenging activities of the marine microalgae Chlorella stigmatophora and
Phaeodactylum tricornutum. Phytother Res, 15, 224-230

28. Kamat JP, Boloor KK, Devasagayam TPA (2000) Chlorophyllin as an effective antioxidant against membrane damage in vitro and ex vivo. Biochim Biophys Acta, 1487, 113-127

29. Kumar SS, Devasagayam TPA, Bhushan B, Verma NC (2001) Scavenging of reactive oxygen species by chlorophyllin : an ESR study. Free Radic Res, 35, 563-574

30. Kwak YJ, Kim JS (2009) Changes of chlorophyll and SOD-like activities of Chinese chives dehydrated at different heat treatments. J Korean Soc Food Sci Nutr, 38, 879-884

31. Park HM, No HK, Lee SH, Yoon KS, Park CS, Hong JH (2013) Quality characteristics of microencapsulated $\beta$-carotene prepared by different molecular weight chitosan, J Chitin Chitosan, 18, 26-31

32. Rosenberg M, Kopelman IJ, Talmon Y (1990) Factors affecting in spray-drying microencapsulation of volatile materials. J Agric Food Chem, 50, 139-144

33. Lee KW (1998) Studies on the microencapsulation of lactic acid bacteria and their survival. $\mathrm{Ph} \mathrm{D}$ Thesis. Seoul University, Korea

34. Kim JW, Park IK, Yoon KS (2013) Phytochemical compounds and quality characteristics of spray-dried powders with the blanching condition and selected forming agents from pressed extracts of Ligularia fischeri leaves. Korean J Food Preserv, 20, 659-667

35. Moon JH, Kim RS, Choi HD, Kim YS (2010) Nutrient composition and physicochemical properties of Korean taro flours according to cultivars. Korean J Food Sci Technol, 42, 613-619

36. Beom HJ, Kang DJ, Lee BD, Shon J, Im JS, Eun JB (2007) Physicochemical characteristics of powder from hot air and freeze dried leaves and roots of Acorous calamus L. J Korean Soc Food Sci Nutr, 36, 1451-1457

37. Park HM, Chae HY, Hong JH (2015) Physicochemical properties and protease activities of microencapsulated pineapple juice powders by spray drying process. Korean J Food Preserv, 22, 84-90

38. Bae EK, Kim GH (2008) Encapsulation of avocado oil using spray drying. Korean J Food Sci Technol, 40, 303-310

39. Kagami Y, Fujishima N, Matsuda K, Kometani T, Matsumura Y (2003) Oxidative stability, structure, and physical characteristics of microcapsules formed by spray drying of fish oil with protein and dextrin wall materials. J Food Sci, 68, 2248-2255 